\title{
Experimental Investigation and Comparison of Fatigue Behavior of E-Glass, Corbon Fiber and Jute Fiber Reinforced Polymer Matrix Composite used as Implants
}

\author{
Shivanand N Pujar ${ }^{1}$ \\ ${ }^{1}$ Research Scholar, \\ Lecturer, Dept of Mechanical Engineering, \\ Govt. Polytechnic Hubli, India \\ Dr. K. R Dinesh ${ }^{2}$ \\ ${ }^{2}$ Principal and Professor, \\ Dept. of Mechanical Engineering, \\ Government Engineering College, Raichur, India
}

\author{
Dr. Jagadish S $\mathrm{P}^{3}$ \\ ${ }^{3}$ Assistant Professor, \\ Department of Mechanical Engineering, \\ RYMEC, Ballari, India \\ Dr. ShivaKumar Gouda ${ }^{4}$ \\ ${ }^{4}$ Assosiate Professor, \\ Department of Mechanical Engineering and \\ Deputy Dean CIII, SDMCE-Dharwad,, India.
}

\begin{abstract}
This research paper constitutes the Fatigue behavior of E-glass fiber corbon and jute fibre reinforced polymer composite and study of $10 \%$ weight fraction E-glass fiber corbon and jute fibre reinforced polymer composite fabricated by using Hand Layup fabrication technique According to the ASTM Standard Fatigue test was conducted ie ASTM D3479 / D3479M - 19 and ASTM D-3039 Standard the specimen is fabricated by using the Epoxy resin- LY556 as the matrix material and the Hardener-HY 951 with the $10 \%$ E-glass fiber corbon and jute fibre as the reinforcement material with fiber weight fraction, $0+/-90^{0}$ fiber orientation. By using the Hand Layup fabrication technique the specimens are prepared and the fatigue tests conducted on $E$ glass fiber, carbon and jute fibre polymer composites fatigue strength evaluated. The tests are conducted under static tension and cyclic tension with mean fatigue stress equal to $10 \%$ of the $E$ glass fiber, corbon and jute fibre polymer composites tensile strength. The experimental results show the Gradually the cyclic load is applied for the $10 \%$ E-GFRP carbon and jute fibre Specimen, From the experimental results the cyclic load $@ 40243$ CYCLES with182.4MPa the E-Glass fibre polymer Composite at Failure ie $100 \%$ amount of E-Glass fibre cracks/delimitation takes place or fibre At Failure. Similarly Jute polymer Composite Fails at 23809 Cycles with $19.86 \mathrm{MPa}$ and Carbon Fibre Composites Fails At $10^{6}$ cyclic Load with1100 MPa and compare with human Tebia bone.
\end{abstract}

Keywords-Tension-Tension Fatigue of Polymer Matrix Composite Materials, E-GFRP, corbon and jute fibre, tibia bone.

\section{INTRODUCTION}

The development of composite materials and related design and manufacturing technologies is one of the most important advances in the history of materials. Composites are multifunctional materials having unprecedented mechanical and physical properties that can be tailored to meet the requirements of a particular application. Many composites also exhibit great resistance to Fatigue loading. Fatigue is the Phenomena of material failure or it may be structural damage occurs when subjected to reparative loading or cyclic loading. In this paper elaborative study is done on the failure behavior of Carbon /E-glass/Jute fiber Reinforced Polymer Composites by tensile-tensile fatigue tests under a sinusoidal waveform loading at two different loading frequencies, 5 and $30 \mathrm{~Hz}$, using a load amplitude control mode, and a ratio between minimum and maximum stress $(\mathrm{R})$ of 0.1 .

The research is carried out to predict the fatigue life of the patient's lower leg bones along with identifying the regions of the bones which are weaker in terms of strength of Tibia and Fibula bones of a patient suffering from lower leg pain [2]. Failure phenomena occur with increasing stress levels and duration, which can lead to material damage or degradation. The Mean Stress, Amplitude and orientation of the varying load with respect to fiber direction decide the characteristic of fibre cracks/delimitation[3]. The stresscontrolled tensile fatigue behavior at a stress ratio of $\mathrm{R}=0.1$ were performed on GFRP composites, The fatigue life of the GFRP composite was increased by about three to four times due to the silica nanoparticles[4] .The influence of compressive, zero, and tensile mean strains on fatigue life and on the stress train histories during fatigue were examined on cortical bone specimen from human femora, The total number of cycles to fatigue failure was influenced only by the total strain range and was not affected by mean strain[5]. Fatigue failure of hybrid polymer which is prepared with the mixture of cashew nut shell liquid (CNSL) resin and polyester resin was analyzed to optimize the composition parameters and for the improvement of biocompatibility [6]. The effect of load interruptions on the fatigue behavior of $( \pm 45) 2 \mathrm{~s}$ angle-ply glass/epoxy composite laminates was investigated. Constant amplitude fatigue experiments were performed at different stress levels, The specimens loaded under interrupted fatigue exhibited longer fatigue live than those continuously loaded until failure [7]. The experimental results of the influence of water ageing on Glass fiber and Kevlar-fiber composites 
shows that the residual stiffness and residual strength decreased when the immersion time and cycle number of fatigue increased, indicating that the studied composites have experienced some forms of mechanical damage[8]. It was observed that moisture saturation has a detrimental stress-dependent effect on the fatigue strength of the epoxy/E-glass composite .The stiffness during the fatigue cycles was similar for both dry and water-saturated coupons [9]. Tension- Tension fatigue tests were performed on woven jute fibres with epoxy matrix composites with a constant fatigue stress ratio $(\mathrm{R}=0.1)$ and results obtained from the tests were used to plot S-N Curve [10].

\section{MATERIALS AND TEST METHODS}

This chapter describes the details of processing of the composites and the experimental procedures followed for their characterization and fatigue evaluation. The raw materials used in this work are: E-glass fiber, corbon ,jute fibre and Epoxy resin

\subsection{METHODOLOGY}

Characterization is carried out using Epoxy resin -LY556 as a matrix material, hardener -HY 951 and (a)10\% Carbon fibres as the reinforcement material (with fiber weight fraction, $0 \pm 900$ orientation ie orthotropic material) (b) $10 \%$ Jute fibres as the reinforcement material (with fiber weight fraction, $0 \pm 900$ orientation ie orthotropic material) (c) $10 \%$ E-Glass fibres as the reinforcement material (with fiber weight fraction, $0 \pm 900$ orientation ie orthotropic material by using Hand lay up technique.

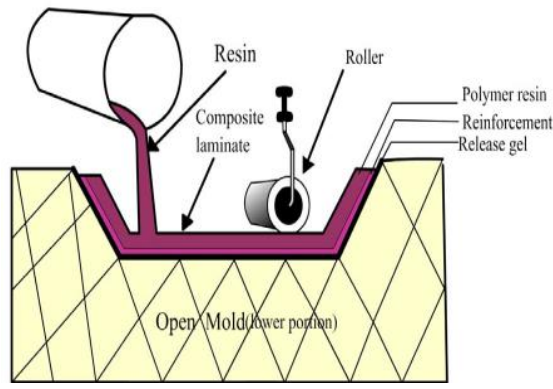

Figure: 2.1 Hand Lay Up Method

2.2. OBJECTIVE The objective of the present study is:

1. To study the Fatigue behaviour E-GFRP, corbon and jute fibre composites implants.

2. To report Fatigue behaviour with cyclic loads results.

\section{EXPERIMENTAL PROCEDURE}

\subsection{PROPERTIES OF jute fibre}

Table 3.1: Properties of jute fibre

Table 3.1: Physical and mechanical properties of Natural

\begin{tabular}{|l|l|l|l|l|}
\multicolumn{5}{|c|}{ Fibers [60-61] } \\
\hline Fiber & $\begin{array}{l}\text { Density } \\
(\mathrm{g} / \mathrm{cm} 3)\end{array}$ & $\begin{array}{l}\text { Elongation } \\
(\%)\end{array}$ & $\begin{array}{l}\text { Tensile } \\
\text { Strength } \\
(\mathrm{MPa})\end{array}$ & $\begin{array}{l}\text { Elastic } \\
\text { Modulus } \\
(\mathrm{MPa})\end{array}$ \\
\hline Jute & 1.3 & $1.5-1.8$ & $393-773$ & 26500 \\
\hline Hemp & 1.47 & $2-4$ & 690 & 70000 \\
\hline Sisal & 1.5 & $2.0-2.5$ & $511-635$ & $9400-22000$ \\
\hline Banana & 1.3 & $3-3.2$ & $540-549$ & $29000-$ \\
& & & & 32000 \\
\hline
\end{tabular}

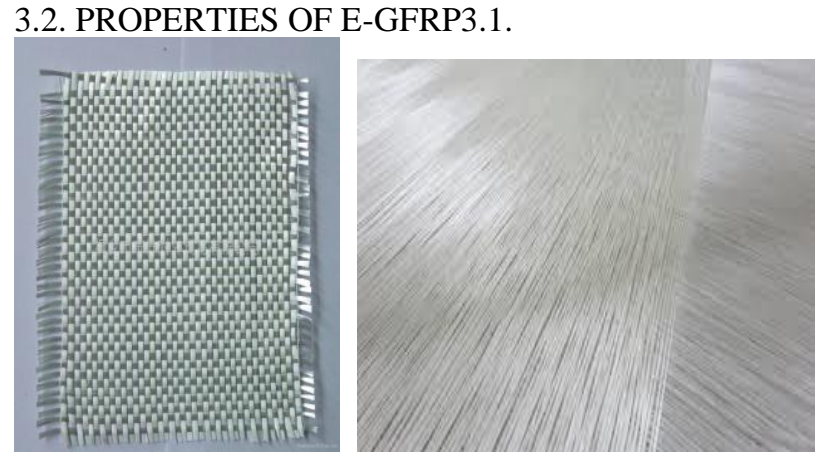

Fig:3.1 E-glass fibers

Table 3.2: Mechanical properties of E-GLASS FIBER

\begin{tabular}{|l|l|}
\hline PROPERTY & E-GLASS FIBER \\
\hline Density [g/cm3] & 2.58 \\
\hline Tensile strength [N/mm2] & \multicolumn{2}{|c|}{$1950-2050$} \\
\hline Compression Strength [N/mm2] & $4000-5000$ \\
\hline Young's modulus in N/mm2 & 73 \\
\hline \multicolumn{1}{|c|}{ Poisson's ratio } & 0.21 \\
\hline \multicolumn{2}{|c|}{ Shear modulus in N/mm2 } \\
\multicolumn{2}{|l}{}
\end{tabular}

Table 3.3: Mechanical properties of Carbon Fiber

\begin{tabular}{|c|c|}
\hline PROPERTY & CARBON FIBER \\
\hline Density [g/cm3] & 1.298 \\
\hline Tensile strength [N/mm2] & 600 \\
\hline Compression Strength [N/mm2] & 570 \\
\hline Young's modulus in N/mm2 & 113.0 \\
\hline \hline Poisson's ratio & 0.320 \\
\hline Shear modulus in N/mm2 & 3200 \\
\hline
\end{tabular}

\subsection{Specimen preparation}

After fabrication of E-GFRP Laminates, jute fibre Laminates, carbon fibre Laminates, These laminates are cut according to ASTM D3039 Standards by using a Trotec Speed $300 \AA$ laser device in the fibre direction. - Specimens of $250 \mathrm{~mm}$ in length and $25 \mathrm{~mm}$ in width $2.5 \mathrm{~mm}$ in thickness were prepared for tensile monotonic and fatigue testing. These dimensions are in agreement with the ASTM D3039 recommendations. After surface preparation (sanding then cleaning with acetone), tabs made with the same composite materials (40 $\mathrm{mm}$ in length, $15 \mathrm{~mm}$ in width and $1 \mathrm{~mm}$ in thickness) were bonded to the test specimens used a Loctite Super Glue 3 Gel adhesive.

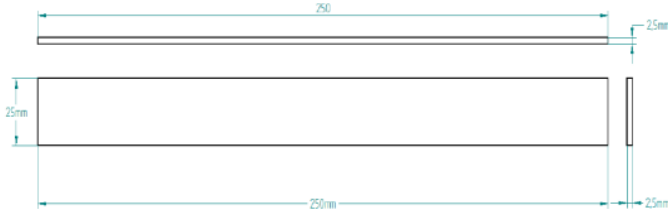

Fig 3.2: Specification of the Tensile Test Specimens as Per the ASTM D3039 Standard. 


\subsection{Digital-Fatigue-Testing-MachinesFTG-8D:-}

This is rotating beam type machine in which load is applied in reversed bending fashion. The standard specimen is held in special holders at its ends and located such that it experiences a uniform bending moment. The specimen is rotated at $4200 \mathrm{rpm}$ by a motor. A complete cycle of reversed stresses in all fibres of the specimen is produced during each revolution. The bending moment is applied with the lever system and can be easily changed by moving a weight over the lever. Total number of revolution at which the specimen fails is recorded by a mechanical counter.

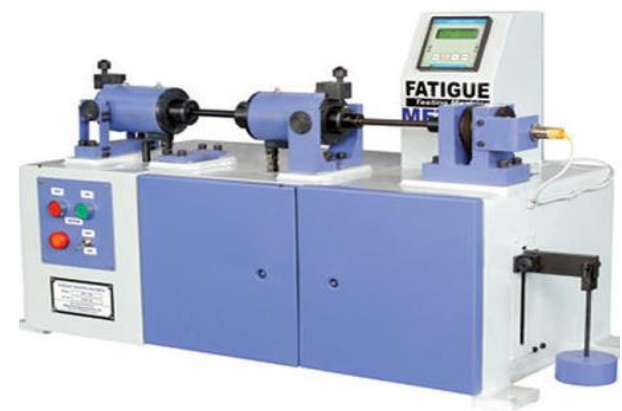

Fig3.3 universal hydraulic fatigue testing machine

TECHNICAL SPECIFICATIONS.MODEL FTG -8(D):Maximum bending movement $\mathrm{kg} \mathrm{cm}$;Bending movement adjustable $\mathrm{kg} \mathrm{cm}$; Ranges I \& II kg cm $25-200 \mathrm{~kg} \mathrm{~cm} 125-$

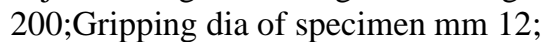

Testing dimension of specimen mm--250X25X3mm Rotating speed rpm 4200;Accuracy of applied bending movement;Digital counter No. of digits 8;Power required HP 0.5 Main supply $3 \mathrm{hp}, 440, \mathrm{~V}, 50 \mathrm{~Hz}$, A.C;Overall size (approx) mm 1000L.X.; Weight ( approx) kg 120

3.6 Procedure of Tensile Fatigue Tests:- The tensile-tensile fatigue tests were performed under a sinusoidal waveform loading at two different loading frequencies, 5 and $30 \mathrm{~Hz}$,

using a load amplitude control mode, and a ratio between minimum and maximum stress (R) of 0.1.

The experimental configuration (loading machine, specimen shape and preparation) was similar to monotonic tensile tests. Fatigue tests were performed in the fibre direction. Six levels of maximum stress were applied. The levels were $100,150,200,250$, and $280 \mathrm{~N}$ for three replicates were tested at each stress level. Tests were stopped at failure. At $30 \mathrm{~Hz}, \mathrm{~A}$ complete cycle also recorded with fatigue load
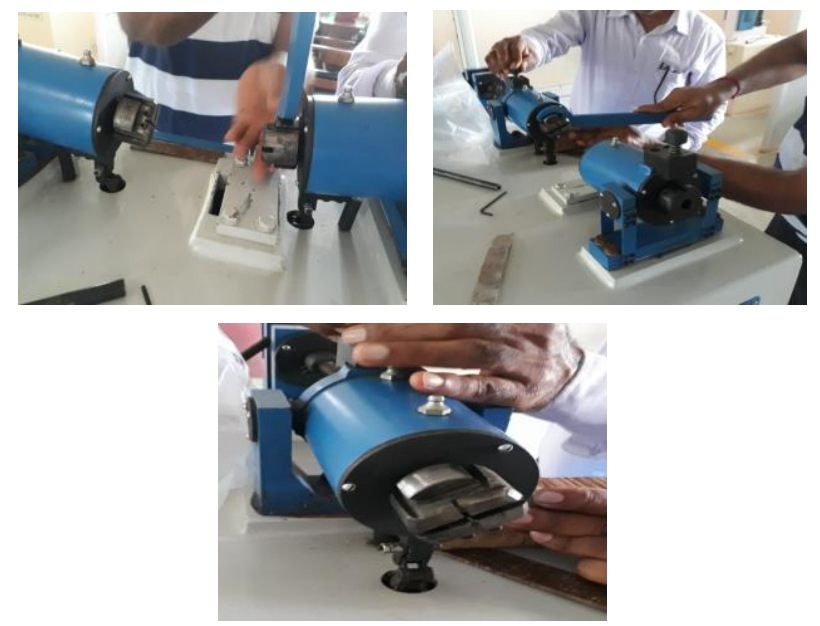

Fig3.4(a),(b),(c) Flat Fixture to hold the specimen according to ASTM D3039 Standard and Fixing the Fixture for Flat Specimen.
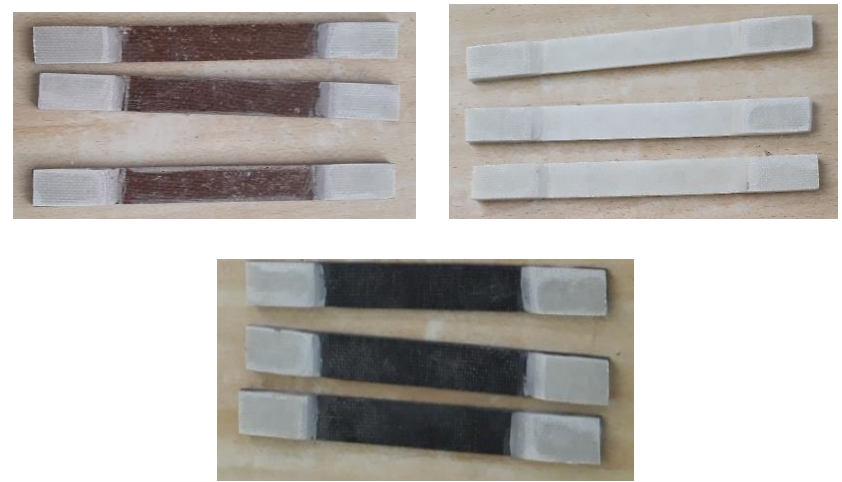

Fig3.5 (a)Jute fibre composite (b) E-Glass fibre composite (c) Corbon fibre composite as Per the ASTM D-3039 Standard

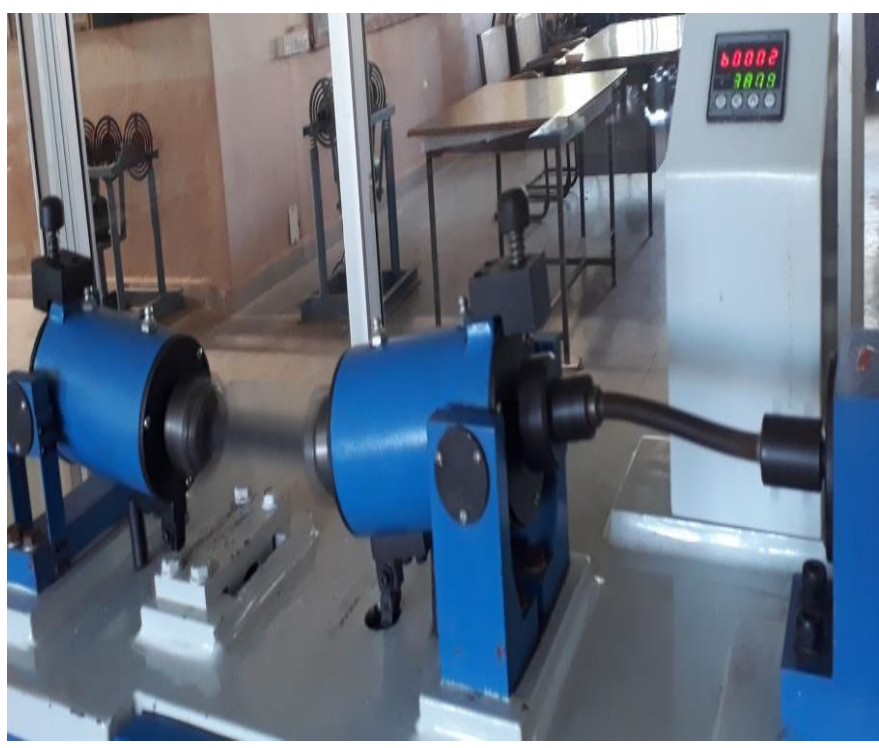

A. Fig3.6 Fatigue Test On Jute polymer Composite ---- Failure @23809 Cycles 


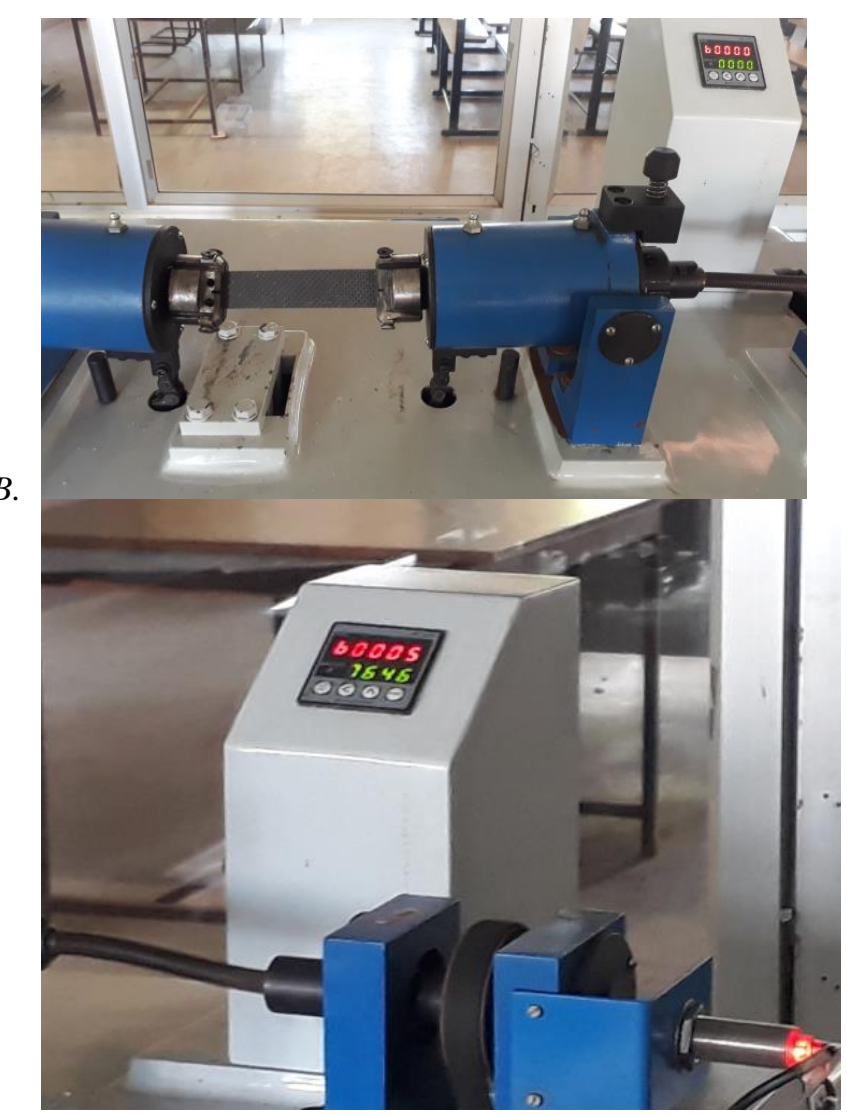

Fig3.7 Carbon Polymer Composites Slipped From Jaw @57646 CYCLES At Failure And Also Continued The Experiment The Corbon Fibre Composites Fails At 106cyclic Load.

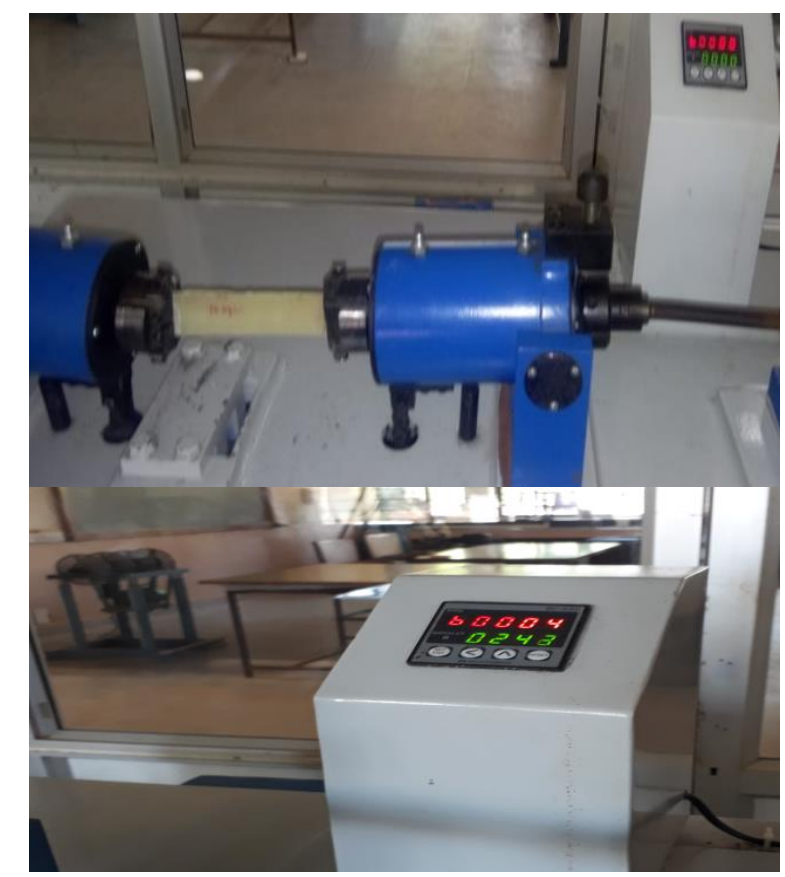

Fig3.8Fatigue test on JUTE polymer composite @ 40243 CYCLES At Failure

\subsection{Types of Tests with ASTM Standards:}

Fatigue experiments were performed by applying two types of loading patterns.

1.Constant amplitude fatigue experiments were performed at different stress levels to derive base line fatigue data.

2.In addition, interrupted-fatigue experiments were performed by removing the cyclic loading for two hours repetitively 3.After cycling for $20 \%$ of the fatigue life achieved under continuous loading at the same maximum cyclic stress level. The specimens loaded under interrupted fatigue exhibited longer fatigue live than those continuously loaded until failure.

Table 3.4: Tensile -Tensile fatigue test Results.

\begin{tabular}{|c|c|c|c|c|}
\hline $\begin{array}{l}\text { specime } \\
\text { n }\end{array}$ & stress & $\begin{array}{l}\text { Various cyclic } \\
\text { load }\end{array}$ & $\begin{array}{l}\text { Status of Fibre } \\
\text { delamination property }\end{array}$ & Conclusion \\
\hline $\begin{array}{l}\text { Jute } \\
\text { polymer } \\
\text { Compos } \\
\text { ite (S1) }\end{array}$ & $\begin{array}{l}19.86 \\
\mathrm{MPa}\end{array}$ & $\begin{array}{l}\text { Failure @23809 } \\
\text { Cycles }\end{array}$ & $\begin{array}{l}100 \% \text { amount of fibre } \\
\text { cracks/delamination } \\
\text { takes place or fibre At } \\
\text { Failure }\end{array}$ & $100 \%$ Failure \\
\hline \multirow{4}{*}{$\begin{array}{l}\text { E-Glass } \\
\text { fibre } \\
\text { polymer } \\
\text { Compos } \\
\text { ite(S2) }\end{array}$} & \multirow{4}{*}{$\begin{array}{l}182.4 \\
\mathrm{MPa}\end{array}$} & $\begin{array}{l}\text { cyclic load } \\
\text { Starting } \\
\text { Point@00000 } \\
\text { CYCLES }\end{array}$ & $\begin{array}{l}\text { Zero amount of fibre } \\
\text { cracks/delamination } \\
\text { takes place }\end{array}$ & 0\%Failure \\
\hline & & $\begin{array}{ll}\text { Cyclic } & \text { load } \\
@ 10220 & \\
\text { CYCLES } & \end{array}$ & $\begin{array}{l}\text { little amount of fibre } \\
\text { cracks/delamination } \\
\text { takes place }\end{array}$ & 40\%Failure \\
\hline & & $\begin{array}{ll}\text { Cyclic } & \text { load } \\
\text { @30388 } & \\
\text { CYCLES } & \end{array}$ & $\begin{array}{l}80 \% \text { amount of fibre } \\
\text { cracks/delamination } \\
\text { takes place }\end{array}$ & $80 \%$ Failure \\
\hline & & $\begin{array}{l}\text { Cyclic load } \\
@ 40243 \\
\text { CYCLES fibre At } \\
\text { Failure }\end{array}$ & $\begin{array}{l}100 \% \text { amount of fibre } \\
\text { cracks/delamination } \\
\text { takes place or fibre At } \\
\text { Failure }\end{array}$ & 100\%Failure \\
\hline $\begin{array}{l}\text { Carbon } \\
\text { Polymer } \\
\text { Compos } \\
\text { ites(S3) }\end{array}$ & $\begin{array}{l}1100 \\
\mathrm{MPa}\end{array}$ & $\begin{array}{l}\text { Carbon Polymer } \\
\text { Composites } \\
\text { Slipped From Jaw } \\
\text { @57646 } \\
\text { CYCLES At } \\
\text { Failure And Also } \\
\text { Continued The } \\
\text { Experiment The } \\
\text { Corbon Fibre } \\
\text { Composites Fails } \\
\text { At } 10^{6} \text { cyclic Load }\end{array}$ & $\begin{array}{l}100 \% \text { amount of fibre } \\
\text { cracks/delamination } \\
\text { takes place or fibre At } \\
\text { Failure }\end{array}$ & 100\%Failure \\
\hline
\end{tabular}

Table 3.4: Consolidated Tensile -Tensile fatigue test Stress, No of Cycles compared with Tibia Bone Fatigue Strength

\begin{tabular}{|c|c|c|c|}
\hline Material Properties & $\begin{array}{c}\text { Experimental } \\
\text { In No of Cycles }\end{array}$ & Stress & $\begin{array}{c}\text { Tibia } \\
\text { Bone } \\
\text { Fatigue } \\
\text { Strength } \\
{[2]}\end{array}$ \\
\hline Jute /Epoxy(S1) & 23809 & $19.86 \mathrm{MPa}$ & \multirow{3}{*}{$\begin{array}{l}18593 \\
\text { Cycles of } \\
\text { life for } \\
\text { Diseased }\end{array}$} \\
\hline E-glass/Epoxy(S2) & 40243 & $182.4 \mathrm{MPa}$ & \\
\hline Carbon /Epoxy(S3) & $>10^{6}$ & $1100 \mathrm{MPa}$ & \\
\hline
\end{tabular}




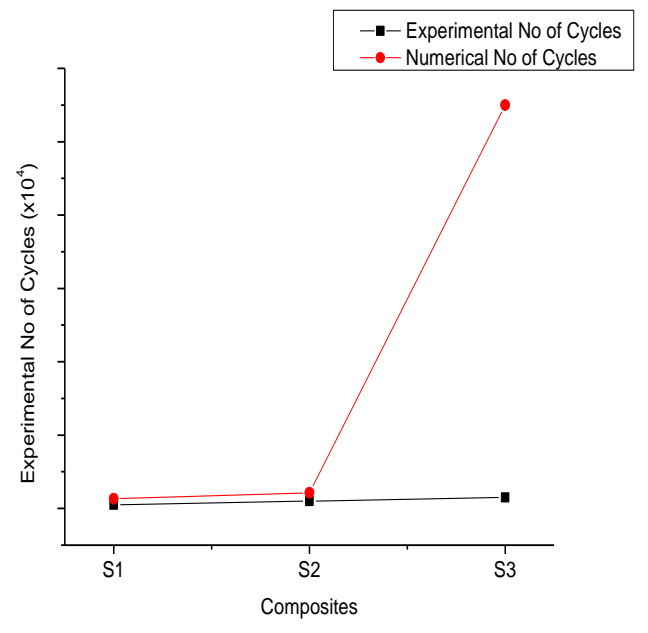

Graph 3.1:-.shows Composites vs No of Cycles.

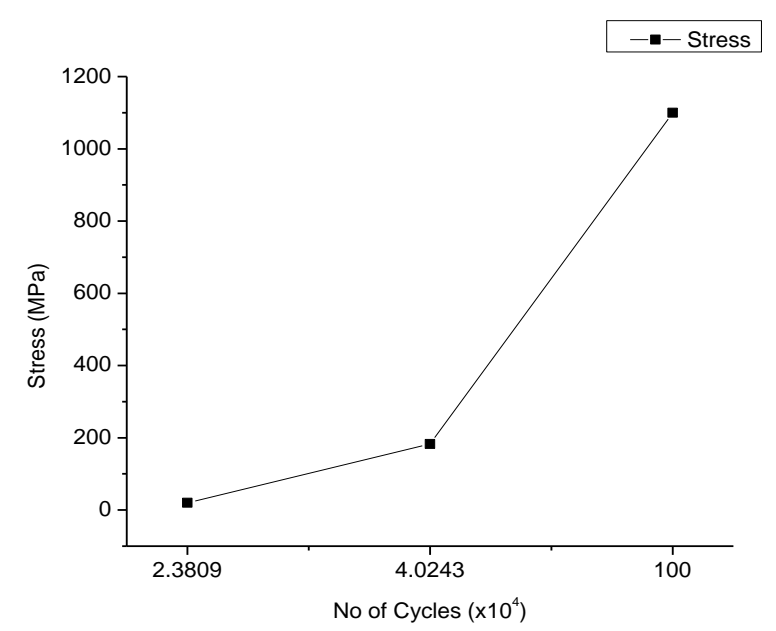

Graph.3.2:shows Stress vs No of Cycles.

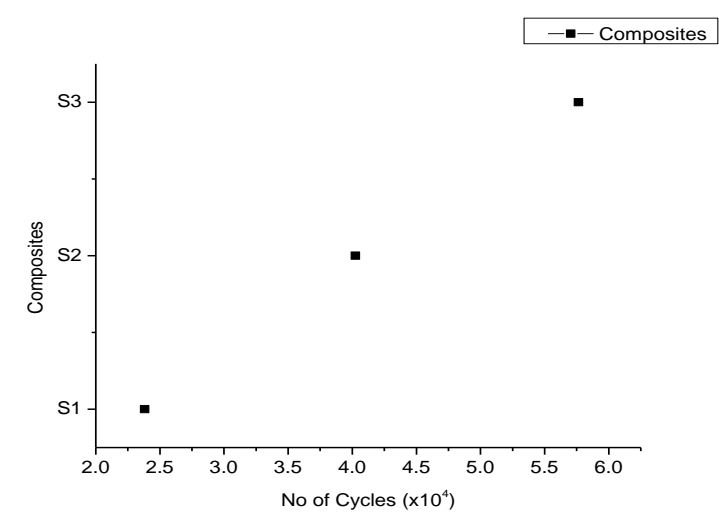

Graph.3.3:shows Composites vs No of Cycles

\section{CONCLUSION}

1. According to experimental results, $10 \%$ Carbon fibers Polymer Composite Material of Fatigue test has Fatigue strength of $1100 \mathrm{MPa}$ for specimen S3 ,10\% E-Glass fibers Polymer Composite Material of Fatigue strength of $182.4 \mathrm{MPa}$ for specimen S2 and $10 \%$ Jute fibers Polymer Composite Material of Fatigue strength of $19.86 \mathrm{MPa}$ From these results it is found that Tebia Fatigue strength of 18593 cycles of life for Deseaed.

2. $10 \%$ Carbon fibers Polymer Composite Material of Highest Fatigue strength of $1100 \mathrm{MPa}$ compare to other two specimen $\mathrm{S} 1$ and $\mathrm{S} 2$.Hence based on Fatigue strength recommending to the medical field.

3. From the experimental results the cyclic load @ 40243 CYCLES with182.4MPa the E-Glass fibre polymer Composite at Failure ie $100 \%$ amount of EGlass fibre cracks/delamination takes place or fibre At Failure similarly. Jute polymer Composite Fails at 23809 Cycles with $19.86 \mathrm{MPa}$ and Corbon Fibre Composites Fails At $10^{6}$ cyclic Load with $1100 \mathrm{MPa}$ and compare with human tebia bone ie 18593 cycles of life for Deseaed.

4. At Failure ie $100 \%$ amount of Jute fibre, E-Glass fibre, Corbon Fibre cracks/delamination takes place or fibre At Failure and also Under both loading patterns, failure was observed in the form of fiber pull-out; however, in specimens loaded continuously failure occurred with considerable necking. At low stress levels, failure with predominant fiber breakage under both loading patterns was observed the fiber stretching

\section{REFERENCES}

[1] www.Googlesearch.com

[2] JFATIGUE LIFE PREDICTION OF TIBIA AND FIBULA BONES USING FINITE ELEMENT METHODRishi Kumar Srivastaval, Syed Nizamulla2, J. Jagadesh Kumar3, G. Ravi Teja4 1,2Final Year B.Tech Student, Department of Mechanical Engineering, Vidya Jyothi Institute of Technology, Hyderabad, India 3Associate Professor, Department of Mechanical Engineering, Vidya Jyothi Institute of Technology, Hyderabad, India 4Final Year M.Tech Student, Department of Mechanical Engineering, Vidya Jyothi Institute of Technology, Hyderabad, India.

[3] Evaluation and Modeling of the Fatigue Damage Behavior of Polymer Composites at Reversed Cyclic Loading Ilja Koch 1, , Gordon Just 1, Martin Brod 2, Jiuheng Chen 3 , Audrius Doblies 4, Aamir Dean 2, Maik Gude 1, Raimund Rolfes 2, Christian Hopmann 3 and Bodo Fiedler 4.

[4] The tensile fatigue behaviour of a silica nanoparticle-modified glass fibre reinforced epoxy composite C.M. Manjunatha *, A.C. Taylor, A.J. Kinloch, Department of Mechanical Engineering, Imperial College London, South Kensington Campus, London SW7 $2 A Z, U . K$. 
[5] Fatigue Behavior of Adult Cortical Bone: The Influence of Mean Strain and Strain Range Acta Orthopaedica Scandinavica ISSN 0001-6470 (Print) (Online) Journal homepage: https://www.tandfonline.com/loi/iort19 Dennis R. Carter, William E. Caler, Dan M. Spengler \& Victor H. Frankel To cite this article: Dennis R. Carter, William E. Caler, Dan M. Spengler \& Victor H. Frankel (1981) Fatigue Behavior of Adult Cortical Bone: The Influence of Mean Strain and Strain Range, Acta Orthopaedica Scandinavica, 52:5, 481-490, DOI: 10.3109/17453678108992136
this article https://doi.org/10.3109/17453678108992136Acta orthop. scand. 52, 481-490, 1981 .

[6] INVESTIGATION ON FATIGUE STRENGTH OF THE JUTE FIBER REINFORCED HYBRID POLYMER MATRIX COMPOSITES P. Prabaharan GRACERAJ1, G. VENKATACHALAM2, A.Gautham SHANKAR3, Krishna KUMAR4U.P.B. Sci. Bull., Series D, Vol. 78, Iss. 1, 2016 ISSN 1454-2358.

[7] Effect of Loading Pattern on Fatigue Behavior of Laminated Composites $\dagger$ Abdolvahid Movahedi-Rad, Thomas Keller and Anastasios P. Vassilopoulos *Composite Construction Laboratory (CCLab), Ecole Polytechnique Fédérale de Lausanne (EPFL), Lausanne 1015, Switzerland; abdolvahid.movahedirad@epfl.ch (A.V.M.-R.); thomas.keller@epfl.ch (T.K.) * Correspondence: anastasios.vasilopoulos@epfl.ch; $\quad$ Tel.: T41-21-6936393† Presented at the 18th International Conference on Experimental Mechanics (ICEM18), Brussels, Belgium,1-5 July 2018 Published: 12 June 2018Proceedings 2018, 2, 438 doi:10.3390/ICEM18-05321 www.mdpi.com/journal/proceedings.

[8] Effect of Fatigue Testing and Aquatic Environment on the Tensile Properties of Glass and Kevlar Fibers Reinforced Epoxy Composites Menail Y1, Abderrahim EL Mahi2* and Assarar M3 1University of Badji Mokhtar, Sidi Ammar, LR3MI, BP 12, 23000, Annaba, Algeria 2University of Maine, LAUM, CNRS UMR 6613, Avenue Olivier Messiaen, 72085 Le Mans Cedex 9 France 3University of Reims Champagne-Ardenne, LISM, EA 4695, IUT de Troyes, 9 rue de Québec, 10026 Troyes Cedex, FranceJournal of Aeronautics \& Aerospace Engineering Journal of Aeronautics \& Aerospace Engineering ISSN: 2168-9792 Menail et al., J Aeronaut Aerospace Eng 2015, 4:3 DOI: 10.4172/21689792.1000150

[9] Immersed Fatigue Performance of Glass Fibre-Reinforced Composites for Tidal Turbine Blade Applications R. Kennedy1,2 • S. B. Leen 1,2 • C. M. O ' Bra'daigh3 Received.

[10] Fatigue Behaviour and Life Assessment of Jute-epoxy Composites under Tension-Tension Loading. Padmaraj N H1, Chethan K N1,Pavan1, Onkar Anand1 1Department of Aeronautical and Automobile Engineering, Manipal Institute of Technology, Manipal University, Manipal, India- 576104 